Байкальский государственный университет, 2. Иркутск, Российская Федеращия

M. А. Балашова

Байкальский государственный университет, 2. Иркутск, Российская Федерация

И. Ю. Науменко

Байкальский государственный университет, г. Иркутск, Российская Федерация

\title{
РОЛЬ АТОМНОЙ ЭНЕРГЕТИКИ В ПРОТИВОДЕЙСТВИИ НЕГАТИВНЫМ ПОСЛЕДСТВИЯМ ГЛОБАЛИЗАЦИИ
}

\begin{abstract}
АНнотАция. Глобализация, ставшая реальностью в XXI в., результате поступательных действий стран, ориентированных на внешнеэкономическое развитие, принесла с собой угрозы, защититься от которых развивающемуся миру оказалось очень сложно. Ее лидеры связывают это с низким уровнем конкурентоспособности стран, вступивших в единое экономическое пространство позже, и, соответственно, видят выход в повышении качества внутриэкономического развития. Однако, искусственно созданные условия организации международного сотрудничества не дают в настоящее время шансов на реальный экономический рост. Наблюдая за тем, что таким странам развивающегося мира как Россия и Китай, сделавшим в свое время ставку на развитие атомной энергетики и создание ядерного оружия, все-таки удается в определенной степени защищать свою национальною безопасность, по их пути пошли и другие развивающие страны. Однако получить ожидаемого результата им не удается, так как значение атомной энергетики и государственная политика в данной сфере для стран, генерирующих ее, за минувший век существенно изменились. В связи с этим, развивающемуся миру необходимо продолжить работу по поиску вариантов противодействия потери национального суверенитета в условиях глобализации мировой экономики.

кЛючЕВыЕ словА. Глобализация; атомная энергетика; ядерные державы; государственная политика; национальная безопасность.

ИНФОРМАЦИЯ О СТАТЬЕ. Дата поступления 25 апреля 2017 г.; дата принятия к печати 11 мая 2017 г.; дата онлайн-размещения 22 июня 2017 г.
\end{abstract}

I. V. Tsvigun

Baikal State University, Irkutsk, Russian Federation

M. A. Balashova Baikal State University, Irkutsk, Russian Federation

I. Yu. Naumenko Baikal State University, Irkutsk, Russian Federation

\section{ROLE OF NUCLEAR ENERGY IN COUNTERACTING NEGATIVE CONSEQUENCES OF GLOBALIZATION}

ABSTRACT. Globalization, that has become a reality in the XXI century as a result of progressive motion of the countries oriented to foreign and economic development, has brought along the treads that are very complicated for the developing world to defend from. Their leaders are connecting this with the low level of competitiveness of the countries that later have entered the united economic space and, accordingly, are seek-

(C) И. В. Цвигун, М. А. Балашова, И. Ю. Науленко, 2017

\section{Baikal Research Journal}


ing the way out in increasing the quality of internal economic development. Anyhow, artificially created terms of arranging international cooperation do not give any chances for real economic growth. Keeping watch over such countries of the developing world like Russia and China, having relied at the proper time on developing nuclear energy and creating nuclear arms, are succeeding none the less in protecting their national security to a certain degree, the other developing countries did follow their way. Yet, they fail to obtain the expected result, as the importance of the nuclear energy and the state policy in this sphere for the countries that generate it have greatly changed. In this regard, the developing world need to continue work in searching for variants of counteracting the loss of national sovereignty in terms of the world economy globalization.

KEYWORDS. Globalization; nuclear energy; nuclear powers; state policy; national security.

ARTICLE INFO. Received April 25, 2017; accepted May 11, 2017; available online June $22,2017$.

Как свидетельствует практика, коррективы, вносимые государствами в принятые формы международных экономических отношений, могут существенным образом изменить облик мировой экономики. В частности, известно, что на первых этапах формирования мирового товарного рынка и рынка услуг они четко сегментировались по странам происхождения своей продукции и, соответственно, их объем был не велик. В результате роста населения (в первую очередь, европейского), и, соответственно, потребительского спроса, производители из разных стран мира вынуждены были начать между собой диалог, который способствовал бы разрешению сложившейся проблемной ситуации. В качестве способа увеличения емкости мировых товарных рынков была выбрана унификация торговых правил и законов, заниматься которой должны были вновь создаваемые структуры. Так, появился Ганзейский торговый союз, ставший прообразом новой группы субъектов мировой экономики - международных экономических организаций.

Чуть позже желание ведущих стран - метрополий (в первую очередь, Англии и Голландии) принимать непосредственное участие в освоение ресурсной базы своих колоний, воплощенное на практике, привело к началу процессов транснационализации мировой экономики.

Ликвидация в первой трети XX в. таможенных пошлин и нетарифных барьеров в торговле между тремя монархиями Европы (Бельгия, Нидерланды, Люксембург) стала первым этапом интеграции в Европе; между ЮАР, Лесото, Свазиленд, Ботсваной и Намибией — в Африке; между Коста-Рикой, Никарагуа, Гондурасом, Гватемалой и Сальвадором - в Латинской Америке.

Принятое в 1947 г. многостороннее межправительственное соглашение о снижении торговых барьеров в международной торговле товарами и услугами, дало толчок началу очередной волны внешнеэкономической либерализации после периода достаточно жесткого протекционизма периода Великой экономической депрессии и Второй мировой войны и пр.

В результате произошедших изменений, инициаторами которых, фактически являлись одни и те же страны, экономика которых в наибольшей степени зависела (и продолжает зависеть) от объемов и качества внешнеэкономических связей, мировая экономика шагнула в эпоху глобализации.

Изначально международное сообщество предполагало, что плюсы от открытия национальных границ, формирования единого торгового, финансового, информационного, культурного пространства перекроют для всех стран - участниц данного процесса неизбежные минусы, как на микро, так и на макроуровнях экономического анализа. Однако на практике выяснилось, что с более ассиметричным процессом в плане «вклад - выгода» субъекты мировой экономики еще не сталкивались [1].

\section{Baikal Research Journal}


Во-первых, в результате активно идущих процессов интернационализации, транснационализации, интеграции, регионализации, либерализации, экономики участвующих в них стран открылись примерно в одинаковой степени, однако приращение львиной доли преимуществ от глобализации стала получать лишь небольшая группа стран мира. А, во-вторых, сделанная ставка на рыночную экономику и либерализацию, должны были привести к формированию совершенно конкурентных мировых товарных рынков и рынков услуг. Однако следствием все тех же тенденций развития современной глобальной экономики стал переход к рынкам с несовершенной конкуренцией и олигополией. А мировой порядок фактически стал однополярным [2;3].

Примечательным, на наш взгляд, является способ, которым лидеры глобализации (фактически одна страна - США, а официально целая группа - «Группа 7») простым, но вроде бы научно обоснованным языком пытаются объяснить остальному международному сообществу образовавшийся между ними разрыв. Это - разница в уровне конкурентоспособности (на всех уровнях экономического анализа), и сложившийся тип организации экономики (индустриальное или постиндустриальное общество) [4; 5]. Огромный штат сотрудников специально созданных международных структур на постоянной основе трудится над созданием новых и над совершенствованием системы оценки ранее созданных критериев, которые унифицированы и подходят для любой национальной экономики. В их число входят: отраслевая структура валового внутреннего продукта, индекс человеческого развития, индекс уровня образования, уровень расходов на научно-исследовательские и опытно-конструкторские работы (НИОКР), уровень научно-исследовательской активности, индекс инноваций, индекс глобальной конкурентоспособности, индекс сетевой готовности, индекс развития информационно-коммуникационных технологий, уровень развития Интернета, индекс развития электронного правительства и пр.

Достигнутое каждой страной значение и качество предлагаемых показателей на системной основе объясняет, почему ее экономика не может считаться высококонкурентоспособной и в каком направлении ей необходимо двигаться, для того, чтобы перейти от использования сравнительных к созданию и получению отдачи от конкурентных преимуществ. Так, например, в одной из авторитетных в настоящее время методик оценки уровня национальной конкурентоспособности, разработанной специалистами Института развития менеджмента, базирующегося в Лозанне, практикуется моделирование ситуации, при которой конкурентоспособность страны возможно улучшить. Проводя расчеты текущего значения индекса глобальной конкурентоспособности, специалисты выделяют порядка 20 самых проблемных показателей, затем заменяют их значение на среднее по анализируемым странам, и определяют, в конечном итоге, новый ранг страны по анализируемому критерию.

Безусловно, интересный подход, в котором ключевыми, на наш взгляд, являются два момента. Во-первых, это ставка на состязательность. Не важно, что сравниваются между собой страны с разными моделями экономического развития, разным цивилизационным фундаментом, историческим наследием и пр. Важен чисто психологический фактор: в ситуации сравнения никогда не хочется быть худшим. И, во-вторых, это акцент на внутренних экономических проблемах: хочешь быть лучшим - совершенствуй себя [6;7].

Ни в одной из действующих международных методик не объясняется парадокс XXI в.: если ты страна догоняющего типа развития, в число лидеров глобализации тебе ни при каких условиях не попасть. В условиях открытых границ, когда мировые рынки уже фактически монополизированы более конкурентоспо-

\section{Baikal Research Journal}

электронный научный журнал Байкальского государственного университета 
собными игроками, участь остальных - быть донорами. И чем больше страна будет вкладываться в совершенствование собственных конкурентных преимуществ, тем быстрее они будут уходить за границу [8].

Страшная ситуация, которую развивающийся мир достаточно хорошо понимает и даже некоторые страны пытаются ей противостоять. Поскольку искусственно созданные условия организации и осуществления международного экономического сотрудничества не дают в настоящее время шансов на национальное развитие, ставка этими странами делается на внешнеполитическое воздействие и/или наращивание военной мощи.

Выбор политики в качестве способа перелома ситуации связан с тем, что в современном мире демократии и свободы решения международных структур зачастую являются весомыми и носят стратегический характер. А, поскольку участие во внешнеполитических дебатах на различных площадках принимает большинство стран мира, поэтому, гипотетически, выговорить для себя некоторые льготы могут многие. Однако практика свидетельствует о том, что реальный шанс есть только у стран - членов международных межправительственных организаций, специализация которых представляет непосредственный интерес для развития конкретной национальной экономики, и чьи выносимые решения являются обязательными для реализации. Примеров таких организаций не много, но они есть. Это - Организация стран - экспортеров нефти (ОПЕК), Всемирная торговая организация (ВТО), Международное агентство по атомной энергии (МАГАТЭ), Всемирная организация здравоохранения (ВОЗ) и др. Особняком, на наш взгляд, стоит одна структура - один из главных органов ведущей комплексной международной межправительственной организации - Совет безопасности Организации объединенных наций $(\mathrm{OOH})$. С одной стороны, его специализация достаточно узкая - миротворческая деятельность и никак не связана с возможностью корректировки уровня и темпов национального экономического развития. Однако, с другой стороны, последние годы работы данной структуры показывают реальные примеры того, как, решая вопросы мира и войны, можно повлиять на национальную экономическую безопасность (как в лучшую, так и в худшую сторону). Соответственно в наиболее выигрышной ситуации (по сравнению с другими странами мира) сегодня находятся те, кто обладает правом «вето» в Совет безопасности ООН. Конкретно из стран развивающегося мира это Россия и Китай, которое они получили как основательницы Ядерного клуба (вместе с США, Францией и Великобританией).

Сталкиваясь воочию с тем, что созданная еще в середине XX в. отрасль атомной энергетики может давать стране столь существенные бонусы в XXI в., в группе стран развивающегося мира сложился еще один блок - те, кто в плане противостояния экономической экспансии стран - лидеров глобализации выбрали вариант наращивания собственной военной мощи со ставкой на ядерную энергетику. Речь, в первую очередь, идет об Иране и Северной Корее, которая, проводя политику протекционизма, все равно испытывает на себе давление США. Выбор данных стран объясним, однако их руководству следует абсолютно четко понимать, что значение атомной энергетики в плане развития национальной экономики за минувший век изменилось существенным образом и гарантировать защиту национальной безопасности она уже не может.

Как свидетельствует история, главным фактором активного развития данной отрасли в середине XX в. стала гонка вооружений. Когда за счет военного противостояния, ставшего возможным в результате достижения высочайшего уровня научно-технического прогресса (НTП), две мощнейшие сверхдержавы (СССР и США) пытались изменить структуру мирового порядка от биполярного в сторону

\section{Baikal Research Journal}

электронный научный журнал Байкальского государственного университета 
однополярного. Соответственно не будет ошибочным утверждение, что на этапе своего зарождения энергия атома «покорилась» научному сообществу, работающему над военными программами: промышленные ядерные реакторы использовались для производства оружейного плутония для атомных бомб. Первыми в данном соперничестве стали американцы. В 1942 г. в США под руководством Э. Ферми был построен первый ядерный реактор. С небольшим опозданием добились аналогичных результатов в СССР, чуть позже в Великобритании, Франции, Китае и др. странах мира (табл. 1).

Таблица 1

\section{Эволюция развития атомной энергетики в мире}

\begin{tabular}{|c|c|c|c|}
\hline $\begin{array}{c}\text { Этап развития } \\
\text { отрасли }\end{array}$ & $\begin{array}{c}\text { Основная } \\
\text { характеристика } \\
\text { этапа }\end{array}$ & $\begin{array}{c}\text { Страны - } \\
\text { производители } \\
\text { атомной энергии }\end{array}$ & $\begin{array}{c}\text { Значение отрасли для } \\
\text { страны - производителя } \\
\text { атомной энергии }\end{array}$ \\
\hline 1940-1950-е гг. & $\begin{array}{l}\text { Создание ядерных } \\
\text { реакторов для про- } \\
\text { изводства атомных } \\
\text { бомб }\end{array}$ & $\begin{array}{l}\text { США, СССР, } \\
\text { Великобритания }\end{array}$ & $\begin{array}{l}\text { Гарантия национальной безо- } \\
\text { пасности за счет укрепление } \\
\text { позиций в качестве мощной } \\
\text { военной державы; повышение } \\
\text { статуса в структуре мирового } \\
\text { порядка }\end{array}$ \\
\hline 1950-1960-е гг. & $\begin{array}{l}\text { Создание первого } \\
\text { поколения энерге- } \\
\text { тических реакторов } \\
\text { малой мощности }\end{array}$ & $\begin{array}{l}\text { Великобритания, } \\
\text { США, СССР, } \\
\text { Франция }\end{array}$ & $\begin{array}{l}\text { Стимулирование НТП в стране } \\
\text { за счет растущих потребностей } \\
\text { в сложных технологиях, позво- } \\
\text { ляющих вырабатывать энергию } \\
\text { путем оптимизации использова- } \\
\text { ния природных ресурсов и пе- } \\
\text { реработки облученного топлива } \\
\text { для извлечения из него урана } \\
\text { и плутония; удовлетворение } \\
\text { растущего внутреннего «энерге- } \\
\text { тического» спроса }\end{array}$ \\
\hline $\begin{array}{l}\text { Конец } 60-\mathrm{x}- \\
\text { начало 90-х гг. } \\
\text { ХХ в. }\end{array}$ & $\begin{array}{l}\text { Создание второго } \\
\text { поколения «мир- } \\
\text { ных» энергетиче- } \\
\text { ских реакторов }\end{array}$ & $\begin{array}{l}\text { Великобритания, } \\
\text { США, СССР, Фран- } \\
\text { ция, Китай, Индия, } \\
\text { Канада, Испания, } \\
\text { Германия, Южная } \\
\text { Корея, Япония и др. }\end{array}$ & $\begin{array}{l}\text { Расширение доли атомной энер- } \\
\text { гетики в структуре энергоба- } \\
\text { ланса стран, производящих ее. } \\
\text { Использование энергия атома } \\
\text { становится экспортным това- } \\
\text { ром, а значит и дополнитель- } \\
\text { ным источником национального } \\
\text { дохода }\end{array}$ \\
\hline $\begin{array}{l}\text { Конец } 90-\mathrm{x} \mathrm{гг.} \\
\mathrm{XX} \mathrm{в.} \mathrm{-} \\
\text { по настоящее } \\
\text { время }\end{array}$ & $\begin{array}{l}\text { Создание третьего } \\
\text { поколения реакто- } \\
\text { ров с улучшенными } \\
\text { эксплуатационны- } \\
\text { ми показателями, } \\
\text { низкими выбросами } \\
\text { радиоактивности в } \\
\text { окружающую среду }\end{array}$ & $\begin{array}{l}\text { Финляндия, Фран- } \\
\text { ция, Китай, Индия, } \\
\text { Россия, в ряде стран } \\
\text { таких как ОАЭ, } \\
\text { Турция, Белоруссия } \\
\text { и другие, строитель- } \\
\text { ство осуществляется } \\
\text { на сегодняшний день }\end{array}$ & $\begin{array}{l}\text { Использование атомной энер- } \\
\text { гии в целях обеспечения } \\
\text { энергетической безопасности } \\
\text { и диверсификации источников } \\
\text { производства энергии. Исполь- } \\
\text { зование атомных технологий } \\
\text { способствует созданию рабочих } \\
\text { мест в смежных отраслях }\end{array}$ \\
\hline К 2030-е гг. & $\begin{array}{l}\text { Создание четвертого } \\
\text { поколения систем } \\
\text { атомной технологии }\end{array}$ & $\begin{array}{l}\text { Страны, участвую- } \\
\text { щие в разработках } \\
\text { перспективных } \\
\text { реакторов 4-го } \\
\text { поколения: Канада, } \\
\text { Китай, Россия, США, } \\
\text { Франция, Япония, } \\
\text { Ю. Корея и др. }\end{array}$ & $\begin{array}{l}\text { Использование новых систем, } \\
\text { обладающих более высокими } \\
\text { эксплуатационными показате- } \\
\text { лями, чем предыдущие поко- } \\
\text { ления, обеспечит страны более } \\
\text { дешевыми и экологичными (без } \\
\text { вредных отходов) видами энер- } \\
\text { гии, тепла, системами опресне- } \\
\text { ния воды }\end{array}$ \\
\hline
\end{tabular}

Составлено по материалам [9-11]; Планы по строительству российских реакторов в РФ и за рубежом, а также оценка реалистичности их воплощения // Атомный эксперт. 2014. № 1-2. С. 66-73, а также Международного форума 4-го поколения (GIF). URL : https://www.gen-4.org/

\section{Baikal Research Journal}


Получив в руки столь уникальную «дирижерскую палочку» дальнейшего развития мировой экономики, ядерные державы становятся постоянными членам созданного в 1945 г. Совета безопасности $\mathrm{OOH}$, и одна за другой начинают проводить испытания нового вида оружия: в 1945 г. - США, в 1949 г. - CССР, в 1952 г. - Великобритания, в 1960 г. - Франция, в 1964 г. - Китай.

На наш взгляд, именно фактор первенства на этапе зарождения отрасли атомной энергетики, когда она, в первую очередь, была поставлена на службу развития военной индустрии, до сих пор позволяет странам - основательницам Ядерного клуба не только активно участвовать в дискуссиях о будущем мирной мировой экономики, но и гарантировать собственную национальную экономическую безопасность, обеспечивать национальный суверенитет. Последующий же ход развития данной отрасли постепенно привел ее к числу одной из отраслей в энергобалансе страны и, естественно, трансформировал выполняемые ею функции.

В частности, убедившись на практике в собственной военной мощи, все те же страны начинают постепенно переводить атомную энергетику в мирное русло. Так, в 1950-1960-х гг. в Великобритании, США, СССР и Франции создается первое поколение энергетических реакторов малой мощности, предназначенных для простой выработки энергии. Это была попытка осуществить «устойчивое развитие реакторной технологии» (в частности, путем оптимизации использования природных ресурсов и переработки облученного топлива для извлечения из него урана и плутония). За счет того, что на данном этапе отрасль нуждалась в достаточно сложных технологиях, помимо простого удовлетворения растущего внутреннего «энергетического» спроса, она стимулировала развитие НТП в стране.

Переход ко второму поколению «мирных» энергетических реакторов происходит достаточно быстро (уже в конце $60-x$ гг.) и выводит атомную энергетику на промышленный уровень. Фактически одновременно в 30 странах мира строятся атомные электростанции (АЭС) и постепенно использование энергии атома становится экспортным товаром. Для стран-производителей атомной энергии это означает появление дополнительных источников национального дохода.

Третье поколение реакторов с улучшенными эксплуатационными показателями, низкими выбросами радиоактивности в окружающую среду появляется в конце 1990-х гг. Некоторые их виды продолжают производиться и в настоящее время. Как правило, они относятся к реакторам с легководным теплоносителем и могут иметь вид:

- EPR-1600 (производства компании «Areva»), строящиеся в Финляндии, Франции и Китае;

- AP-1000 (усовершенствованный легководный реактор производства «Westinghouse»), сторящийся в Китае и США;

- ВВЭР-1200 (проект «АЭС-2006», разработанный ОКБ «Гидропресс») в России и Белоруссии;

- APR-1400 (производства «КЕРСО») в ОАЭ¹.

К более современным типам ядерных реакторов специалисты МАГАТЭ относят:

- PWR (pressurized water reactors) - водо-водяной энергетический реактор (реактор с водой под давлением) использующий в качестве замедлителя и теплоносителя обычную (легкую) воду, также называющийся легководным;

- BWR (boiling water reactor) - кипящий реактор в котором пар генерируется непосредственно в активной зоне и направляется в турбину;

- FBR (fast breeder reactor) - реактор-размножитель на быстрых нейтронах, который позволяет нарабатывать ядерное топливо в объеме, большем, чем потребности самого реактора. Сырьем для нового топлива служат изотопы, которые не

\footnotetext{
${ }^{1}$ Лицензирование реактора АР1000 - драма с моралью // Атомный эксперт. 2013. № 9. С. 39-44.
}

\section{Baikal Research Journal}


могут быть использованы в традиционных энергетических реакторах, например, уран-238 и торий-232. При этом в зоне размножения из обедненного урана, состоящего, в основном, из урана-238, получается плутоний-239, который может быть использован в реакторе, как новое ядерное топливо;

- GCR (gas-cooled reactor) - газоохлаждаемый реактор;

- LWGR (light water graphite reactor) - графито-водный реактор гетерогенный, использующий в качестве замедлителя графит, а в качестве теплоносителя - обычную воду. По уран-графитовой схеме были созданы первые экспериментальные и промышленные реакторы для АЭС. В том числе реактор первой в мире АЭС был уран-графитовым (реактор АM);

- PHWR (pressurised heavy water reactor) - тяжеловодный реактор который в качестве теплоносителя и замедлителя использует тяжелую воду. Так как дейтерий имеет меньшее сечение поглощения нейтронов, чем легкий водород, такие реакторы имеют улучшенный нейтронный баланс (то есть для них требуется менее обогащенный уран), что позволяет использовать в качестве топлива природный уран в энергетических реакторах или использовать «лишние» нейтроны для наработки изотопов.

На сегодняшний день в мире 31 страна эксплуатирует 191 атомную электростанцию с 449 энергоблоками общей электрической мощностью около 392168 МВт, 60 энергоблоков находятся в стадии строительства, 160 энергоблоков закрыты, еще 2 не работают, однако решение об окончательном закрытии пока не принято ${ }^{2}$.

Предполагается, что с введением к 30 -м гг. XXI в. четвертого поколения атомной технологии термин «реактор» будет заменен на более корректный - «система», который включит в себя как непосредственно сам реактор, так и цикл по переработке ядерного топлива [12] (рис.).

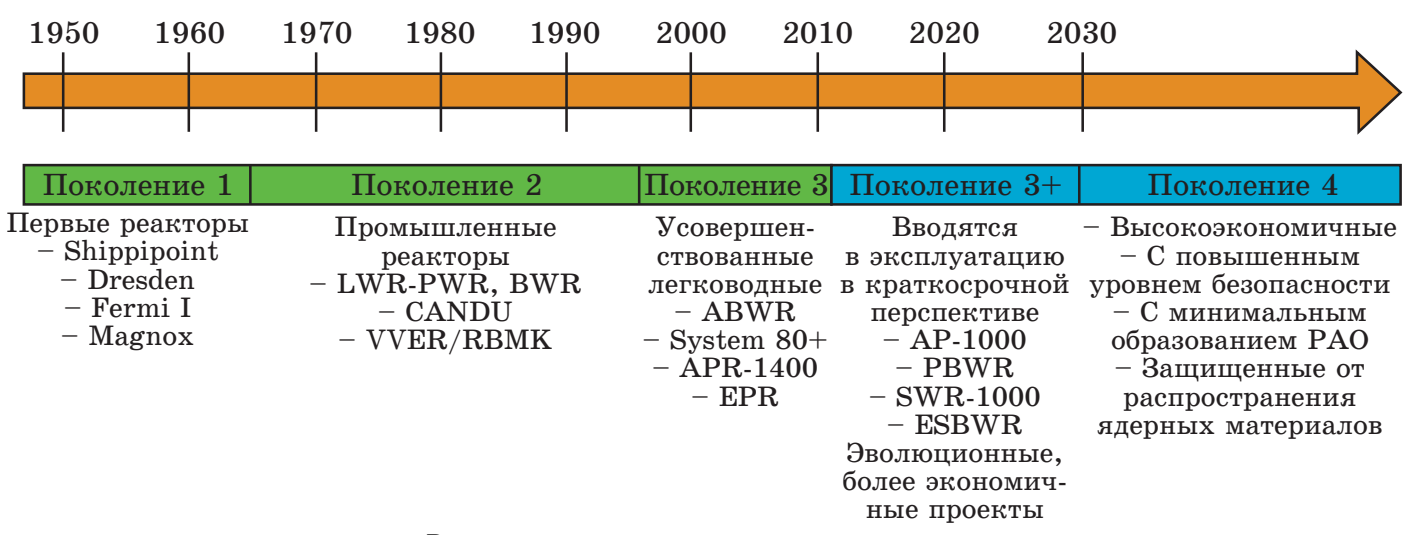

\section{(Источник: http://www.atomic-energy.ru/te-chnology/34307)}

На данном же этапе происходящие изменения в отрасли позволяют нам сделать следующие выводы:

1. Несмотря на отказ некоторых стран от использования энергии атома, отрасль, очевидно, продолжает развиваться, производить новые виды ядерных реакторов, способствовать созданию новых товаров и целых отраслей: атомный ледокольный флот, ядерная медицина, ядерная и радиационная безопасность и др. ${ }^{3}$

${ }^{2}$ База данных PRIS MAГАTЭ [Электронный pecypc]. URL: https://www.iaea.org/pris/.

${ }^{3}$ Причины отказа ряда стран от дальнейшего развития атомной энергетики // Атомный эксперт. 2013. № 6-7. C. 52-63.

\section{Baikal Research Journal}


Это, в свою очередь (так же, как и на предшествующих этапах), способствует развитию науки в стране - производителе атомной энергии и приращению полезностей для нее, как материального, так и политического плана, хотя, безусловно, способствовать защите национального суверенитета, как это было на этапе ее зарождения, она больше не может [13]. Данный вывод подтверждается еще и тем фактом, что, по большому счету, основными потребителями атомной энергии сегодня являются страны, способные ее генерировать (табл. 2).

В частности, безусловным лидером по использованию атомной энергетики в XXI в. являются США, где общая электрическая мощность близка к 100 ГВт, а также строится 4 энергоблока. Во Франции, где доля атомной энергетики в общем энергобалансе страны очень высока, сильны «европейские настроения» по отказу от энергии атомного ядра, в пользу альтернативных источников, таких как солнечная, ветряная, тем не менее, строится один новый энергоблок. Китай находится в лидерах не только по использованию атомной энергии, но по строительству, возводя 20 новых энергоблоков на своей территории, как своими силами, так и с привлечением других стран ${ }^{4}$.

Таблица 2

Ведущие страны по использованию атомной энергетики на декабрь 2016 г.

\begin{tabular}{|c|c|c|c|c|}
\hline Страна & $\begin{array}{c}\text { Общая } \\
\text { электрическая } \\
\text { мощность, МВт }\end{array}$ & $\begin{array}{c}\text { Доля атомной энергетики } \\
\text { в общей выработке } \\
\text { электроэнергии в стране } \\
\text { в } 2015 \text { г., \% }\end{array}$ & $\begin{array}{c}\text { Количество } \\
\text { атомных } \\
\text { электростанция }\end{array}$ & $\begin{array}{l}\text { Количество } \\
\text { энергоблоков }\end{array}$ \\
\hline США & 99869 & 19,5 & 60 & 99 \\
\hline Франция & 63130 & 76,3 & 19 & 58 \\
\hline Япония & 39752 & 0,5 & 17 & 42 \\
\hline Китай & 32384 & 3,0 & 13 & 37 \\
\hline Россия & 26111 & 18,6 & 10 & 35 \\
\hline Южная Корея & 23077 & 32,7 & 6 & 25 \\
\hline Канада & 13554 & 16,6 & 4 & 19 \\
\hline Украина & 13107 & 56,5 & 4 & 15 \\
\hline Германия & 10799 & 14,1 & 7 & 8 \\
\hline Швеция & 9740 & 34,3 & 3 & 10 \\
\hline Всего (в мире) & 392116 & 10,9 & 191 & 449 \\
\hline
\end{tabular}

Составлено по данным Международного энергетического агентства (URL: http://www.iea.org/ publications/freepublications/publication/KeyWorld2016.pdf) и базы данных PRIS MAГATЭ. URL: https://www.iaea.org/pris/

2. Под влиянием повсеместных процессов внутри и внешнеэкономической либерализации, а также исходя из потери стратегического значения отрасли атомной энергетики для страны, производящей ее, наряду с политикой жесткого протекционизма, принятой в XX в., страны - производители мирного атома стали практиковать в XXI в. также политику ядерного либерализма и ядерной дискриминации. Государственное регулирование отраслью сохранилось, поскольку она является чрезвычайно капитало- и наукоемкой, однако две из пяти стран - основательниц Ядерного клуба (США и Великобритания) пошли на значительные послабления в отрасли и впустили в нее негосударственный сектор экономики (табл. 3).

K первому направлению сегодня тяготеют страны с ярко выраженной политикой поддержки «мирного атома», государственным протекционизмом по отношению к отрасли атомной энергетики. Ко второму - страны с относительно нейтральным отношением к данной отрасли. Государственная поддержка атомной

\footnotetext{
${ }^{4}$ Всемирная ядерная ассоциация [Электронный ресурс]. URL: http://world-nuclear.org.
}

\section{Baikal Research Journal}


энергетики в этих странах носит весьма ограниченный характер, в результате чего развитие происходит согласно законам экономической целесообразности, исходя из условий рыночной конъюнктуры. В свою очередь, в третью группу входят страны, в которых атомная энергетика находится в менее благоприятных условиях, чем другие источники генерации энергии.

Совреленные направления государственной политики

Таблица 3 в сфере атомной энергетики

\begin{tabular}{|c|c|c|c|}
\hline Направление & Суть & Характеристики & Представители \\
\hline \begin{tabular}{l|} 
Ядерный \\
протекцио- \\
низм
\end{tabular} & $\begin{array}{l}\text { Государство зада- } \\
\text { ет поступательное } \\
\text { развитие атомной } \\
\text { энергетики незави- } \\
\text { симо от рыночных } \\
\text { условий }\end{array}$ & $\begin{array}{l}\text { Отраслевые ресурсы сосредоточены } \\
\text { в 1-2 компаниях. } \\
\text { Высокий уровень участия государства в } \\
\text { атомной отрасли. } \\
\text { Роль частных НИОКР незначительна. } \\
\text { Контроль всех сфер применения атомной } \\
\text { энергии. } \\
\text { Контроль финансового потока в атомной } \\
\text { отрасли }\end{array}$ & $\begin{array}{l}\text { Россия, } \\
\text { Индия, } \\
\text { Китай, } \\
\text { Южная } \\
\text { Корея, } \\
\text { Франция } \\
\text { и др. }\end{array}$ \\
\hline $\begin{array}{l}\text { Ядерный } \\
\text { либерализм }\end{array}$ & $\begin{array}{l}\text { Государство не } \\
\text { устанавливает па- } \\
\text { раметров развития } \\
\text { атомной отрасли }\end{array}$ & $\begin{array}{l}\text { Контролирующие и надзорные функции } \\
\text { в вопросах, связанных с ядерной безо- } \\
\text { пасностью (сертификация оборудования, } \\
\text { лицензирование проектов и др.) находятся } \\
\text { у государства. } \\
\text { В гражданском ядерно-топливном цикле } \\
\text { преобладают негосударственные компании. } \\
\text { Значительное присутствие негосударствен- } \\
\text { ного капитала в атомной отрасли. } \\
\text { Активное участие негосударственных } \\
\text { структур в НИОКР }\end{array}$ & $\begin{array}{l}\text { Канада, } \\
\text { Финляндия, } \\
\text { США и др. } \\
\end{array}$ \\
\hline \begin{tabular}{|l|} 
Ядерная \\
дискримина- \\
ция \\
\\
\\
\end{tabular} & $\begin{array}{l}\text { Государство устанав- } \\
\text { ливает дискрими- } \\
\text { национные условия } \\
\text { для атомной отрас- } \\
\text { ли, которые ведут } \\
\text { к ее сокращению и } \\
\text { постепенной ликви- } \\
\text { дации или препят- } \\
\text { ствуют развитию }\end{array}$ & $\begin{array}{l}\text { Отказ государства от атомной энергетики } \\
\text { в определенные или гибкие сроки. } \\
\text { Установление запрета на использование } \\
\text { атомной энергии в целях генерации. } \\
\text { Специальное, дискриминационное налого- } \\
\text { обложение атомной энергетики. } \\
\text { Преференции альтернативным источни- } \\
\text { кам генерации энергии }\end{array}$ & $\begin{array}{l}\text { Германия, } \\
\text { Бельгия, } \\
\text { Швейцария, } \\
\text { Тайвань, } \\
\text { Шотландия, } \\
\text { Италия, } \\
\text { Австрия и др. }\end{array}$ \\
\hline
\end{tabular}

Составлено по данным электронного журнала «Атомный эксперт» (URL: http://atomicexpert. com/page255343.html).

Следует отметить, что в каждом направлении существуют как умеренные, так и радикальные варианты политики стран по отношению к ядерной отрасли. Так в группе стран с «ядерным протекционизмом» существуют значительные различия в отношении к зарубежным поставщикам альтернативных ядерных технологий. Некоторые страны практически закрыли свой внутренний рынок (Россия, Франция, Южная Корея), другие, напротив, открыли (Индия, Китай). Группа стран с «Ядерным либерализмом» также разнится от стран с максимально либеральным режимом для атомной энергетики (США), до стран с большим участием госструктур (Канада). Группа стран с «Ядерной дискриминацией» разнится по времени и объему сокращения доли АЭС в общей генерации энергии и полному отказу от атомной энергетики. Так, Германия планирует отказаться от ядерной генерации в 2022 г., Швейцария - предположительно в 2034 г.

Таким образом, резюмируя вышеизложенный материал, можно прийти к следующему выводу. В эпоху быстро происходящих перемен, когда такие категории как «время» и «пространство» стираются, странам, в первую очередь, развива-

\section{Baikal Research Journal}

электронный научный журнал Байкальского государственного университета 
ющегося мира в целях защиты своего национального суверенитета и гарантии национальной безопасности, не следует делать ставку на использование инструментов, созданных в XX в. Получить такой же результат в противостоянии странам - лидерам глобализации, который удалось получить и до сих пор удается (с определенными оговорками) России и Китаю не возможно, поскольку отрасль атомной энергетики, в создании которой они приняли непосредственное участие, свое стратегическое значение потеряла. Новые времена требуют новых подходов.

\section{Список использованной литературы}

1. Практика глобализации: игры и правила новой эпохи / О. В. Братимов, Ю. М. Горский, М. Г. Делягин [и др.]. - М. : Инфра-М, 2000. - 344 с.

2. Балашова М. А. Об эволюции конкуренции на макроуровне экономики и особенностях современной межстрановой конкурентной борьбы / М. А. Балашова // Известия Иркутской государственной экономической академии. - 2013. - № 3 (89). — С. 76-84.

3. Брюне А. Геополитика меркантилизма: новый взгляд на мировую экономику и международные отношения : пер. с фр. / Антуан Брюне, Жан-Поль Гишар. - М. : Новый хронограф, 2012. - 232 с.

4. Белл Д. Эпоха разобщенности. Размышления о мире XXI века / Д. Белл, В. Иноземцев. - М. : Свобод. мысль, 2007. - 303 с.

5. Портер М. Ю. Международная конкуренция: Конкурент. Преимущества стран : пер. с англ. / М. Ю. Портер. - М. : Междунар. отношения, 1993. - 825 с.

6. Портер М. Ю. Конкурентное преимущество: как достичь высокого результата и обеспечить его устойчивость : пер. с англ. / М. Ю. Портер. - М. : Альпина Бизнес Букс, 2006. -715 c.

7. Шавшуков В. М. Место России в мировой экономике XXI века: конкурентоспособность, сценарии развития / В. М. Шавшуков, Е. М. Гусина // Проблемы современной экономики. - 2014. - № 2 (50). - С. 123-128.

8. Макарова Г. Н. Национальный информационный капитал в условиях глобализации / Г. Н. Макарова, М. А. Балашова. - Иркутск : Изд-во БГУЭП, 2006. - 232 с.

9. Бычков А. Что влияет на атомную энергетику / А. Бычков // Атомный эксперт. 2016. - № 3-4 (45-46). - C. 12-13.

10. Коптелов М. В. Перспективы развития мирового рынка строительства АЭС / М. В. Коптелов // Современные проблемы науки и образования. — 2012. — № 4. - С. 1-8.

11. Кучумов А. Ю. Концепция безопасности проекта «ВВЭР-ТОИ» / А. Ю. Кучумов, А. Ю. Алаев // Росэнергоатом. - 2011. - № 4. - С. 11-15.

12. Субботин С. А. Четыре поколения ядерных реакторов: инновации и современные перспективы [Электронный ресурс] / С. А. Субботин. - Режим доступа: http://pressmia. $\mathrm{ru} /$ pressclub/20151005/950372156.html.

13. Мирсияпов И. И. Российская атомная энергетика: современное состояние и перспективы / И. И. Мирсияпов // Вестник Института экономики Российской академии наук. - 2009. - № 3. - С. 19-29.

\section{References}

1. Bratimov O. V., Gorsy Yu. M., Delyagin M. G. et al. Praktika globalizatsii: igry i pravila novoi epokhi [Practice of globalization: games and rules of new epoch]. Moscow, Infra-M Publ., 2000. 344 p.

2. Balashova M. A. Evolution of competition at the macro level of economy and peculiarities of modern inter-country competition. Izvestiya Irkutskoi gosudarstvennoi ekonomicheskoi akademii = Bulletin of Irkutsk State Economics Academy, 2013, no. 3 (89), pp. 76-84. (In Russian).

3. Brunet A., Guichard J.-P. La visŭe hŭgŭmonique de la Chine, l'impŭrialisme. ǔconomique. Paris, L'Harmattan, 2011. 208 p. (Russ. ed.: Brunet A., Guichard J.-P. Geopolitika merkantilizma: novyi vaglyad na mirovuyu ekonomiku i mezhdunarodnye otnosheniya. Moscow, Novyi khronograf Publ., 2012. 232 p.).

4. Bell D., Inozemtsev V. Epokha razobshchennosti. Razmyshleniya o mire XXI veka [Epoch of disunity. Reflections on the world of the XXI-th century]. Moscow, Svobodnaya mysl' Publ., 2007. 303 p.

\section{Baikal Research Journal}


5. Porter M. E. Competitive Advantage of Nations. New York, Free Press, 1990. 896 p. (Russ. ed.: Porter M. Mezhdunarodnaya konkurentsiya: Konkurent. Preimushchestva stran. Moscow, Mezhdunarodnye otnosheniya Publ., 1993. 825 p.).

6. Porter M. E. Competitive Advantage: Creating and Sustaining Superior Performance. New York, Free Press, 1985. 592 p. (Russ. ed.: Porter M. Konkurentnoe preimushchestvo: Kak dostich' vysokogo rezul'tata i obespechit' ego ustoichivost'. Moscow, Alpina Biznes Buks Publ., 2006. 715 p.).

7. Shavshukov V. M., Gusina E. M. Russia's place in the global economy of XXI-th century: competitiveness, scenarios of development. Problemy sovremennoi ekonomiki $=$ Problems of Modern Economy, 2014, no. 2 (50), pp. 123-128. (In Russian).

8. Makarova G. N., Balashova M. A. Natsionalnyy informatsionnyi kapital $v$ usloviyakh globalizatsii [National Information Capital in the Context of Globalization]. Irkutsk, Baikal State University of Economics and Law Publ., 2006. 232 p.

9. Bychkov A. What influences the nuclear energy. Atomnyi ekspert = Atomic Expert, 2016, no. 3-4 (45-46), pp. 12-13. (In Russian).

10. Koptelov M. V. Prospects of developing the world market of construction atomic power stations. Sovremennye problemy nauki i obrazovaniya $=$ Recent Developments in Science and Education, 2012, no. 4, pp. 1-8. (In Russian).

11. Kuchumov A. Yu., Alayev A. Yu. Security concept for the Project «VVER-TOI». REA. Rosenergoatom $=$ REA. Posenergoatom, 2011, no. 4, pp. 11-15. (In Russian).

12. Subbotin S. A. Chetyre pokoleniya yadernykh reaktorov: innovatsii $i$ sovremennye perspektivy [Four generations of nuclear reactors: innovations and current prospects]. Available at: http://pressmia.ru/pressclub/20151005/950372156.html. (In Russian).

13. Mirsiyapov I. I. Russian nuclear energy: current state and prospects Vestnik Instituta ekonomiki Rossiiskoi akademii nauk = Bulletin of Institute of Economics of Russian Academy of Sciences, 2009, no. 3, pp. 19-29. (In Russian).

\section{Информация об авторах}

Цвигун Ирина Всеволодовна - доктор экономических наук, профессор, кафедра мировой экономики и международного бизнеса, Байкальский государственный университет, 664003, г. Иркутск, ул. Ленина, 11, e-mail: ivtsvigun@mail.ru.

Балашова Мария Александровна - кандидат экономических наук, доцент, кафедра мировой экономики и международного бизнеса, Байкальский государственный университет, 664003 г. Иркутск, ул. Ленина, 11, e-mail: mabalashova@mail.ru.

Науленко Илья Юрьевич - аспирант, кафедра мировой экономики и международного бизнеса, Байкальский государственный университет, 664003 г. Иркутск, ул. Ленина, 11, e-mail: ilyanau@mail.ru.

\section{Authors}

Irina V. Tsvigun - Doctor habil. (Economics), Professor, Chair of World Economy and International Business, Baikal State University, 11 Lenin St., 664003, Irkutsk, Russian Federation; e-mail: ivtsvigun@mail.ru.

Maria A. Balashova - PhD in Economics, Assistant Professor, Chair of World Economy and International Business, Baikal State University, 11 Lenin St., 664003, Irkutsk, Russian Federation; e-mail: mabalashova@mail.ru.

Ilya Yu. Naumenko - PhD Student, Chair of World Economy and International Business, Baikal State University, 11 Lenin St., 664003, Irkutsk, Russian Federation; e-mail: ilyanau@mail.ru.

\section{Библиографическое описание статьи}

Цвигун И. В. Роль атомной энергетики в противодействии негативным последствиям глобализации / И. В. Цвигун, М. А. Балашова, И. Ю. Науменко // Baikal Research Journal. - 2017. - T. 8, № 2. - DOI: 10.17150/2411-6262.2017.8(2).31.

\section{Reference to article}

Tsvigun I. V., Balashova M. A., Naumenko I. Yu. Role of nuclear energy in counteracting negative consequences of globalization. Baikal Research Journal, 2017, vol. 8, no. 2. DOI: 10.17150/2411-6262.2017.8(2).31. (In Russian).

\section{Baikal Research Journal}

